\title{
Peran Model Pembelajaran Group Investigation Berbasis Media Lingkungan Terhadap Kompetensi Pengetahuan IPA
}

\author{
I Putu Lagas Mulyadinata \\ Program Studi Pendidikan Guru Sekolah Dasar, Universitas Pendidikan Ganesha \\ putu.lagas.mulyadinata@undiksha.ac.id
}

I Komang Ngurah Wiyasa

Program Studi Pendidikan Guru Sekolah Dasar, Universitas Pendidikan Ganesha ngrh.wiyasa@undiksha.ac.id

Ni Wayan Suniasih

Program Studi Pendidikan Guru Sekolah Dasar, Universitas Pendidikan Ganesha niwayan.suniasih@undiksha.ac.id

\section{A R T I C LEIN F O}

Article history:

1 Januari 2020 Received in

revised form

30 Mei 2020

Accepted 30 Juni 2020

Available online

15 Juli 2020

\section{Kata Kunci:}

Group Investigation,

media lingkungan,

kompetensi pengetahuan IPA

Keywords:

Reciprocal teachung, environmental media science knowledge

\begin{abstract}
ABSTRAK
Pada muatan materi IPA masih banyak ditemukan siswa yang asyik mengobrol dengan teman kelompoknya sehingga hanya beberapa orang saja yang memperhatikan materi yang dijelaskan oleh guru. Penelitian ini memiliki tujuan untuk mengetahui pengaruh model pembelajaran group investigation berbasis media lingkungan terhadap kompetensi pengetahuan IPA. Jenis pada penelitian ini ialah eksperimen semu dengan menggunakan rancangan nonequivalent control grup design. Polulasi yang terdapat pada penelitian ini adalah sebanyak 174. Sampel diambil menggunakan teknik cluster random sampling untuk menentukan kelompok eksperimen dan juga kelompok kontrol.
\end{abstract} Pengumpulan data untuk kompetensi pengetahuan IPA mempergunakan instrumen tes objektif sebanyak 30 soal yang sudah diujikan instrumen dengan validitas, uji daya beda, indeks kesukaran, dan reliabilitas. Hasil perolehan data kemudian dianalisis dengan uji-t polled varians. Perolehan dari analisis data yaitu $t_{\text {hitung }}=2,979>t_{\text {tabel }}=$ 1,993 pada taraf signifikansi $5 \%$ dengan $\mathrm{dk}=72$, jadi, $\mathrm{H}_{0}$ ditolak dan $\mathrm{H}_{\mathrm{a}}$ diterima. Maka, terdapat perbedaan yang signifikan kompetensi pengetahuan IPA antara kelompok eksperimen dan kelompok kontrol. Jika dilihat dari nilai rata-rata gain skor ternormalisasi kompetensi pengetahuan IPA kelompok eksperimen adalah 0,4 lebih dari kelompok kontrol adalah 0,23. Simpulan dari hal tersebut adalah model pembelajaran group investigation berbasis media lingkungan berpengaruh terhadap kompetensi pengetahuan IPA. Hasil penelitian ini dapat digeneralisasikan di populasi penelitian. Hal ini berarti bahwa model pembelajaran Group Investigation berbasis media lingkungan dapat diterapkan 
science knowledge competencies used 30 objective test instruments that had been tested by instruments with validity, different power tests, difficulty indexes, and reliability. The results of data acquisition were then analyzed by polled variance t-test. Obtained from data analysis that is tcount $=2,979>$ ttable $=1,993$ at the significance level of $5 \%$ with $\mathrm{dk}=72$, so, Ho is rejected and Ha is accepted. Then, there is a significant difference in the competence of natural science knowledge between experimental group and control group. If seen from the average score the normalized score of the science competency competency of the experimental group was 0.4 more than the control group was 0.23 . The conclusion of this is the environmental mediabased group investigation learning model influences the science knowledge competence. The results of this study can be generalized in the study population. This means that the Group Investigation learning model based on environmental media can be applied

\section{PENDAHULUAN}

Pendidikan didefinisikan sebagai suatu pembelajaran pengetahuan, keterampilan, serta kebiasaan sekelompok orang yang diturunkan dari generasi ke generasi yang melalui pengajaran, pelatihan, atau penelitian serta sering terjadi di bawah bimbingan orang lain namun memungkinkan juga terjadi secara otodidak. Segala situasi hidup yang mempengaruhi pertumbuhan dan perkembangan hidup ialah pendidikan (Triyana et al., 2020). Pendidikan merupakan suatu proses yang diperlukan untuk mendapatkan keseimbangan dan kesempurnaan dalam perkembangan individu maupun masyarakat. Penekanan pendidikan dibanding dengan pengajaran terletak pada pembentukan kesadaran dan kepribadian individu atau masyarakat di samping transfer ilmu dan keahlian (Sumertha, 2019). Dalam hal lain pendidikan diartikan usaha secara sadar yang dilakukan manusia untuk menambah pengetahuan, keterampilan dan merubah sikap kearah yang lebih baik (Wibowo, 2019). Tanpa pendidikan, suatu negara akan jauh tertinggal dari negara lain (Sujarwo, 2015). Fungsi pendidikan adalah menghilangkan segala sumber penderitaan rakyat dari kebodohan dan ketertinggalan serta fungsi pendidikan Indonesia menyatakan bahwa pendidikan nasional berfungsi mengembangkan kemampuan dan membentuk watak serta peradaban bangsa yang bermartabat dalam rangka (Sujana, 2019). Selain itu, pendidikan berfungsi sebagai cara atau sarana dalam memajukan peradaban di suatu negara (Junaidi et al., 2019)

Dalam perkembangannya, pendidikan harus tetap mengikuti perubahan yang berlaku dari tahun ke tahun sebagai acuan dalam proses pembelajaran agar perkembangannya semakin berkembang ke arah yang baik. Dalam Undang - Undang Republik Indonesia Nomor 20 Tahun 2003 Tentang Sistem Pendidikan Nasional dinyatakan bahwa seperangkat rencana dan pengaturan mengenai tujuan, isi, dan bahan pelajaran serta cara yang digunakan sebagai suatu pedoman dalam penyelenggaraan kegiatan pembelajaran untuk tercapainya tujuan pendidikan tertentu dapat difenisikan sebagai kurikulum. Kurikulum sering kali mengalami perubahan, ini dikarenakan kurikulum memiliki peran yang sangat penting dalam sistem pendidikan serta dalam setiap proses pembelajaran. Kebijakan perubahan Kurikulum 2013 merupakan sebuah ikhtiar dan wujud dari prinsip dasar kurikulum change and continuity tersebut, yaitu hasil dari kajian, evaluasi, kritik, respon, prediksi, dan berbagai tantangan yang dihadapi (Machali, 1970). Beragam upaya yang sudah dilaksanakan oleh pemerintah dalam upaya peningkatan pendidikan agar ke arah yang semakin maju yaitu dengan pengembangan kurikulum dan kurikulum yang diterapkan saat ini adalah kurikulum 2013. System pendidikan di Indonesia telah beberapa kali mengalami peningkatan seiring dengan perkembangan jaman. Salah satu perubahan yang terjadi pada kurikulum ialah digantinya KTSP menjadi Kurikulum 2013 (Diah Purwati, 2019). Kurikulum memiliki tugas terpenting sebagai pedoman saat proses belajar dan mengajar, hal ini juga menjadi tantangan bagi pemerintah untuk selalu 
menyempurnakan setiap perkembangan yang ada dan pemerintah juga sudah menetapkan kurikulum 2013 di setiap sekolah di seluruh Indonesia (Diantari, 2014).

Peran seorang guru tidaklah lepas dalam penerapan kurikulum 2013. Guru memiliki peran yang penting dalam setiap proses pembelajaran di kelas. Menurut (Buchari, 2018) peran guru dalam pengembangan pengelolaan pengajaran (learning management) dalam tugas-tugas fungsional diantaranya menyusun perencanaan pembelajaran (perumusan tujuan, materi, metode dan teknik, media dan evaluasi belajar), mengorganisasi siswa dalam belajar klasikal dan belajar kelompok di laboratorium/perpustakaan, mengaktualisasi dan memotivasi siswa dalam belajar, mengawasi/mensupervisi untuk memperbaiki belajar siswa dan menilai (evaluasi formatif dan sumatif) prestasi belajar. Namun masih sering ditemukan masalah dalam proses pembelajaran di kelas karena dinilai kurang optimalnya proses pembelajaran yang dilakukan oleh seorang guru. Hal tersebut dapat dilihat dari pelaksanaan pembelajaran di kelas masih terpusat pada guru (teacher center) dan peran serta siswa sangat kurang berpartisipasi dalam proses pembelajaran yang hanya mendengarkan penjelasan guru dan cendrung untuk menggali informasi dari materi yang guru berikan. Dari waktu ke waktu hal tersebut akan mengakibatkan siswa mudah bosan dan menganggap sulit pelajaran di kelas.

Pengembangan materi dalam kurikulum 2013 yang pada kurikulum sebelumnya masih tercantum satu mata pelajaran yang menjadi pokok pembahasan di setiap pertemuan, namun pada kurikulum saat ini materi yang ada sudah diintegrasikan dan dipadukan dalam suatu tema yang disebut tematik terpadu. Kurikulum 2013 terdapat tematik terintergrasi yang memadukan beragam mata pelajaran yang saling berkaitan pada satu tema (Febbriana, 2019). Berbagai mata pelajaran yang sebelumnya hanya diajarkan tersendiri namun sekarang sudah digabung menjadi satu dalam satu tema. Pada kurikulum 2013 dituntut lebih berperan aktif dalam mencari informasi dan menggali pengetahuannya sendiri (Rivaldi et al., 2018). Pada tema terdiri dari beberapa subtema dan dalam subtema tersebut berisikan beberapa pembelajaran (Dewi, 2018)

IPA merupakan salah satu muatan materi yang terdapat pada jenjang sekolah dasar. Sejalan dengan hal tersebut IPA juga merupakan salah satu mata pelajaran pokok dalam kurikulum pendidikan di Indonesia, termasuk pada jenjang sekolah dasar (Purnawan, 2018). Sependapat dengan (Putri, 2019) IPA adalah ilmu yang mempelajari peristiwaperistiwa yang terjadi di alam ini yang terkonstruksi dengan baik secara personal atau sosial. Pengajaran IPA di sekolah dasar hendaknya membuka kesempatan untuk memupuk rasa ingin tahu siswa secara alamiah. Hal ini akan membantu mereka mengembangkan kemampuan bertanya dan mencari jawaban atas berdasarkan bukti serta mengembangkan cara berpikir ilmiah (Mashlichatun, 2018). Muatan materi IPA tidak hanya untuk menyiapkan siswa dalam melanjutkan ke jenjang berikutnya, melainkan guna memberikan kesempatan pada siswa untuk mengembangkan rasa ingin tahu terhadap hal-hal alamiah guna membentuk kepribadian siswa dalam mengembangkan kompetensi pengetahuan mereka. Siswa harus diberi pemahaman bahwa dengan mempelajari IPA siswa akan mendapatkan pengetahuan yang dapat dijadikan bekal dalam menjalani kehidupannya khususnya tentang alam maupun lingkungannya (Anjelina, 2018). Pembelajaran dengan muatan materi IPA di SD menekankan pada pemberian pengalaman belajar secara langsung melalui penggunaan dan pengembangan keterampilan proses dan sikap ilmiah (Lasfeto, 2017). Apabila ingin pembelajaran IPA berjalan dengan baik maka perlu dilaksanakan tindakan (Yanti, 2017). Pembelajaran di kelas juga merupakan faktor utama penunjang dari berjalannya muatan materi IPA. Oleh karena itu, perlu adanya berbagai inovasi dalam menyajikan materi pembelajaran agar berpusat kepada siswa dan juga dapat sebagai penarik perhatian siswa sehingga siswa lebih semangat dalam membangun pengetahuannya. Walaupun muatan materi IPA tersebut termuat dalam pembelajaran tematik, akan tetapi dasar yang tidak kuat akan mengakibatkan siswa kesulitan dalam memahami konsep-konsep yang akan didapatkannya di jenjang selanjutnya. Dalam menanamkan konsep muatan materi IPA dapat dilakukan dengan menyisipkan 
pembelajaran abad 21. Pembelajaran abad 21 dapat diartikan sebagai pembelajaran yang memberikan kecakapan abad 21 kepada peserta didik, yaitu 4C yang meliputi: (1) Communication (2) Collaboration, (3) Critical Thinking and Problem Solving, dan (4) Creative and Innovative (Zubaidah, 2016). IPTEK di era globalisasi ini sangat diperlukan guna menghadapi ancaman global dan berubah-ubahnya pola pikir masyarakat seiring berjalannya waktu. Maka dari itu diperlukannya keterampilan abad 21 dalam menghadapi ancaman tersebut (Suniasih, dkk, 2017)

Pada kenyataannya, pembelajaran yang dilaksanakan di kelas terutama pembelajaran dengan muatan materi IPA masih belum memenuhi harapan yang seharusnya berpusat pada siswa namun malah sebaliknya. Masih banyak terdapat siswa yang mengalami kesulitan dalam pemahaman kompetensi pengetahuan IPA yaitu pada proses pembelajaran siswa kurang memperhatikan pembelajaran yang nantinya mengakibatkan siswa menjadi kurang aktif dalam mengikuti proses pembelajaran. Masih banyak ditemukan siswa yang asyik mengobrol dengan teman kelompoknya sehingga hanya beberapa orang saja yang memperhatikan materi yang dijelaskan oleh guru. Hal ini didukung dengan hasil pengamatan yang dilaksanakan pada saat pelaksanaan PPL Real di SD Negeri 28 Dangin Puri pada tahun 2019.

Berdasarkan permasalahan tersebut, perlunya usaha guru untuk menciptakan pembelajaran yang mampu membangkitkan semangat belajar siswa, membuat pembelajaran bermakna, dan menyenangkan. Pemilihan model pembelajaran sangat penting yang harus disesuaikan dengan materi yang akan disampaikan sehingga terjadi pembelajaran yang aktif (Karwati, 2018). Selain itu, pembelajaran juga harus melibatkan siswa semaksimal mungkin dalam proses pembelajaran. Untuk mengatasi permasalahan tersebut, diperlukan inovasi dalam penyajian muatan materi IPA di kelas seperti menerapkan model pembelajaran yang dapat mendukung proses belajar mengajar. Model pembelajaran yang dapat membantu siswa mengatasi rendahnya partisipasi dan keterampilan siswa adalah model pembelajaran yang dapat melibatkan siswa dalam menyelidiki sesuatu. Salah satu model pembelajaran yang melibatkan siswa dalam proses penyelidikan adalah model pembelajaran kooperatif tipe group investigation.

Model pembelajaran Group Investigation merupakan salah satu model pembelajaran yang sesuai dengan pendekatan statisfik dalam pembelajaran kurikulum 2013 (Lasfeto, 2017). Suatu model pembelajaran yang lebih menekankan pada pilihan serta kontrol pada siswa daripada menerapkan teknik-teknik pengajaran di ruang kelas merupakan definisi dari model group investigation (Aris, 2014). Dengan menerapakan model group investigation siswa dapat ikut berperan aktif di dalam proses pembelajaran dari tahap awal hingga akhir pembelajaran. Karena dalam proses pembelajaran, siswa dibebaskan untuk memilih materi yang akan mereka pelajari sesuai dengan topik yang sedang dibahas. Kelebihan dari model pembelajaran group investigation menurut (Putra, 2019) yaitu pembelajaran berpusat pada siswa (student center) yang mengakibatkan siswa aktif dalam menggali, membangun, dan mengembangkan konsep, setiap tahapan pembelajaran melatih keterampilan proses sains seperti keterampilan mengamati, memprediksi, merancang dan melakukan percobaan, dan mengomunikasikan, dan meningkatkan kerjasama, interaksi, partisipasi siswa dalam proses pembelajaran.

Langkah-langkah model pembelajaran group investigation adalah mengidentifikasi topik, merencanakan investigasi, melaksanakan investigasi, membuat laporan, menyajikan laporan, dan evaluasi (Aisyah, 2018). Dalam penerapan model group investigation pada kompetensi pengetahuan IPA dalam pembelajaran sehari-hari, juga dapat diterapkan dengan berbasis media lingkungan. Media pembelajaran adalah segala sesuatu yang dapat digunakan untuk menyalurkan pesan dan dapat merangsang pikiran, perasaan, perhatian dan kemauan peserta didik sehingga terjadi proses belajar (Program, 2016). Suatu keadaan sekitar dimana dapat mempengaruhi perkembangan dan tingkah laku mahluk hidup termasuk manusia merupakan pengertian dari lingkungan. Penyertaan media lingkungan dalam pembelajaran ini dimaksudkan untuk memberikan kesempatan dan dorongan bagi 
siswa ikut aktif dalam usaha memecahkan masalah serta merespon dengan seluruh kemampuan berpikir, anggota badan, serta segala minat yang dimiliki siswa (Putri, 2013).

Berdasarkan dari pemaparan tersebut, tujuan dan fokus dari penelitian ini adalah untuk mengetahui pengaruh yang signifikan model group investigation berbasis media lingkungan terhadap kompetensi pengetahuan IPA siswa kelas V SDN Gugus I Gusti Ngurah Jelantik Denpasar tahun pelajaran 2019/2020.

\section{METODE}

Jenis penelitian yang dilaksanakan rancangan eksperimen semu (quasi experimental design) yang dipergunakan yaitu rancangan kelompok non-ekuivalen. Tempat pelaksanaan penelitian ini adalah di Gugus I Gusti Ngurah Jelantik Denpasar pada semester II tahun pelajaran 2019/2020. Kelompok eksperimen diberikan perlakuan yaitu dibelajarkan model pembelajaran kooperatif tipe group investigation berbasis media lingkungan, sedangkan kelompok kontrol dibelajarkan pembelajaran konvensional.

Pada sebuah penelitian, populasi maupun sampel merupakan subjek yang akan diteliti. Di dalam penelitian populasi dengan sampel terdapat hubungan yang sangat erat. Penelitian ini dilaksanakan di SDN Gugus I Gusti Ngurah Jelantik Kecamatan Denpasar Utara tahun ajaran 2019/2020 dan seluruh siswa kelas V menjadi populasi yang terdiri atas 5 kelas dari 3 sekolah dasar dengan jumlah keseluruhan yaitu 174. Pada sebuah penelitian tidak memungkinkan menjangkau semua ruang lingkup dalam populasi. Hal tersebut dikarenakan keterbatasan dari beberapa faktor oleh karena itu, digunakanlah sampel yang diperolah dari populasi.

Teknik pengambilan sampel pada penelitian ini yang dirandom kelasnya yang menjadikan semua kelas mendapat peluang untuk menjadi sampel. Sehingga semua kelas V yang ada di lingkungan SDN Gugus I Gusti Ngurah Jelantik Kecamatan Denpasar Utara tersebut mendapat kesempatan yang sama untuk dijadikan sampel. Pada penentuan sampel, dapat digunakan cara yaitu dengan teknik pengundian. Cara undian dilakukan dengan menulis semua kelas V di seluruh SD populasi pada masing-masing kertas yang jumlahnya 5 kelas, kemudian kertas digulung. Lakukan pengundian agar mendapatkan dua kelas. Hasil pengundian tersebut dijadikan sampel penelitian dan kedua kelas yaitu kelas eksperimen dan kelas kontrol dan selanjutnya diberikan pre test. Kemudian skor atau hasil dari pre test tersebut digunakan untuk penyetaraan kelas sampel. Kesetaraan sampel tersebut dianalisis dengan menggunakan rumus uji-t yakni dengan polled varians. Langkah awal dilakukannya uji prasyarat analisis yaitu uji normalitas data dan uji homogenitas varians. Setelah itu, kelompok eksperimen diberikan perlukan dengan dibelajarkan dengan model pembelajaran group investigation berbasis media lingkungan dan kelompok kontrol dibelajarkan menggunakan pembelajaran konvensional.

Data yang digunakan pada penelitian ini adalah mengenai kompetensi pengetahuan IPA. Teknik yang digunakan untuk mengumpulkan data pada sebuah penelitian didefinisikan metode pengumpulan data. Ada banyak dari jenis metode pengumpulan data maupun instrumen pengumpulan data secara garis besar terdapat metode tes dan non tes. Penelitian ini menggunakan metode tes untuk pengumpulan data. Secara garis besar metode tes dan non tes merupakan 2 jenis metode pengumpulan data (Agung, 2014). Pelaksanaan pengumpulan data dilakukan kepada anggota sampel. Tes merupakan salah satunya intrumen yang dapat digunakan untuk mengumpulkan data kompetensi pengetahuan IPA. Tes dimaksudkan sebagai suatu alat bertujuan untuk dipergunakan dalam menghitung ataupun memperoleh sesuatu (Arikunto, 2015). Tes obyektif dalam bentuk pilihan ganda biasa yang digunakan dalam penelitian ini. Namun sebelum siswa diberikan tes maka dilakukan pengujian instrument yaitu uji validitas, daya beda, indeks kesukaran, dan reliabilitas.

Langkah selanjutnya bila data sudah terkumpul, data tersebut perlu dianalisis. Penggunaan analisis pada penelitian ini adalah dengan analisis statistik inferensial. Data 
gain skor yang dinormalisasi dari hasil pre test maupun post test dianalisis dengan statistik inferensial. Teknik analisis pada penelitian ini menggunakan rumus polled varians yang digunakan pada uji-t yang digunakan pada panelitian ini. Uji Hipotesis dengan uji-t menggunakan rumus polled varians. Sebelum melakukan uji-t terlebih dahulu dilakukan uji prasyarat analisis yaitu uji normalitas sebaran data dan uji homogenitas varians.

\section{HASIL DAN PEMBAHASAN}

\section{HASIL}

Berdasarkan hasil analisis data gain score kompetensi pengetahuan IPA kelompok eksperimen yang diberikan perlakuan dengan diberi kegiatan pelajaran menggunakan model pembelajaran group investigation berbasis media lingkungan diperoleh rata-rata (means) sebesar 0,4, standar deviasi sebesar 0,1429, varians sebesar 0,020441, gain skor maksimum sebesar 0,67, dan gain skor minimum sebesar 0,08. Sedangkan, hasil analisis data gain score kompetensi pengetahuan IPA kelompok Kontrol dengan pemberian perlakuan kegiatan belajar menggunakan pembelajaran konvensional. Menurut pemaparan tabel tersebut didapatkan rata-rata (means) sebesar 0,23, standar deviasi sebesar 0,0779, varians sebesar 0,013818 , gain skor maksimum sebesar 0,6 , dan gain skor minimum sebesar 0,13 .

Tabel 01. Rekapitilasi Hasil Analisis Post-test Kompetensi Pengetahuan IPA

\begin{tabular}{lcc}
\hline \multicolumn{1}{c}{ Statistik } & \multicolumn{2}{c}{ Kompetensi Pengetahuan IPA } \\
Kelompok Eksperimen & Kelompok Kontrol \\
\hline Rata-Rata $\bar{X}$ & 0,4 & 0,23 \\
Standar Deviasi & 0,1429 & 0,0779 \\
$(\mathrm{~S})$ & & \\
Varians $\left(\mathrm{S}^{2}\right)$ & 0,020441 & 0,013818 \\
Skor Tertinggi & 0,67 & 0,6 \\
Skor Terendah & 0,08 & 0,13 \\
\hline
\end{tabular}

Salah satu uji prasyarat analisis yaitu uji normalitas sebaran data. Uji normalitas dilaksanakan guna mengetahui sebaran data dari skor kompetensi pengetahuan IPA siswa kelompok eksperimen maupun kontrol berdistribusi normal atau tidak. Uji normalitas sebaran data pada penelitian ini menggunakan uji Kolmogorov-Smirnov, dengan menggunakan taraf signifikansi 5\% yaitu apabila nilai $\mid$ FT - FS $\mid$ terbesar $\leq$ nilai tabel Kolmogorov-Smirnov, oleh karena itu data dapat dinyatakan berdistribusi normal. Uji normalitas sebaran data kelompok eksperimen diperoleh harga nilai maksimum $\left|\mathrm{F}_{\mathrm{T}}-\mathrm{F}_{\mathrm{S}}\right|$ $=0,068<$ harga nilai tabel kolmogorov-smirnov $=0,199$, maka sebaran data dari data gain skor ternormalisasi kompetensi pengetahuan IPA kelompok eksperimen berdistribusi normal. Pada kelompok kontrol harga nilai maksimum $\left|\mathrm{F}_{\mathrm{T}}-\mathrm{F}_{\mathrm{S}}\right|=0,139<$ harga nilai tabel kolmogorov-smirnov $=0,194$, maka sebaran data dari data gain skor ternormalisasi kompetensi pengetahuan IPA kelompok kontrol dinyatakan berdistribusi normal.

Langkah selanjutnya pada uji prasyarat analisis adalah uji homogenitas varians. Uji homogenitas varians dilakukan terhadap data perolehan dari kedua kelompok. Tujuan dari dilakukannya uji homogenitas varians adalah untuk mengetahui varians homogen atau tidak. Pada uji homogenitas varians dipergunakan rumus yaitu dengan menggunakan uji $\mathrm{F}$ (fisher). Berdasarkan hasil perhitungan diperoleh harga $F_{\text {hitung }}=1,48$, angka itu selanjutnya dibandingkan dengan harga $\mathrm{F}_{\text {tabel }}$ dengan taraf signifikansi 5\% $(\alpha=0,05)$ dengan dk untuk pembilang yaitu 38-1 = 37 dan dk untuk penyebut 36-1 = 35, sehingga dapat diperoleh $\mathrm{F}_{\text {tabel }}$ 
$=1,72$, maka dari itu data gain skor ternormalisasi kompetensi pengetahuan IPA dari kedua kelas dinyatakan mempunyai varians yang homogen.

Tabel 02. Hasil Uji Normalitas dan Homogenitas Kelompok Eksperimen dan Kelompok Kontrol

\begin{tabular}{cccccccccc}
\hline No & $\begin{array}{c}\text { Kelompok } \\
\text { Sampel }\end{array}$ & $\mathbf{n}$ & $\mathbf{D k}$ & $\begin{array}{c}\text { Nilai } \\
\text { Maksimum } \\
\mathbf{F}_{\mathbf{T}}-\mathbf{F}_{\mathbf{S}} \mid\end{array}$ & $\begin{array}{c}\text { Nilai Tabel } \\
\text { Kolmogorov } \\
\text {-smirnov }\end{array}$ & Varians & Fhit & Ftabel & Kesimpulan \\
\hline 1 & $\begin{array}{c}\text { Kelompok } \\
\text { Eksperimen }\end{array}$ & 36 & 37 & 0,068 & 0,199 & 0,0204 & & $\begin{array}{c}\text { Berdistribusi } \\
\text { Normal dan } \\
\text { Homogen }\end{array}$ \\
\cline { 1 - 5 } & $\begin{array}{c}\text { Kelompok } \\
\text { Kontrol }\end{array}$ & 38 & 35 & 0,139 & 0,194 & 0,0138 & 1,48 & 1,72 & $\begin{array}{c}\text { Berdistribusi } \\
\text { Normal dan } \\
\text { Homogen }\end{array}$ \\
\hline
\end{tabular}

Setelah dilaksanakannya uji normalitas sebaran data maupun uji homogenitas varians diperoleh data yang berasal dari kedua kelompok dinyatakan berdistribusi normal dan mempunyai varians yang homogen. Maka dari itu, diperolehlah data yang sudah memenuhi uji prasyarat analisis, selanjutnya dapat dilaksanakan uji hipotesis yang menggunakan analisis uji-t yang digunakan adalah rumus polled varians. Kriteria pengujian dari uji-t yaitu jika $t_{h i t u n g} \leq t_{\text {tabel }}$, dinyatakan $\mathrm{H}_{\mathrm{o}}$ diterima. Seandainya jika $\mathrm{t}_{\text {hitung }}$ $>t_{\text {tabel }}$, dinyatakan $\mathrm{H}_{\mathrm{o}}$ ditolak, dengan $\mathrm{dk}=\mathrm{n} 1+\mathrm{n} 2-2$ pada taraf signifikansi $5 \%(\alpha=$ $0,05)$. Berdasarkan hasil perhitungan dan tabel rekapitulasi hasil analisis uji-t, didapatkan $\mathrm{t}_{\text {hitung }}=2,979$ pada taraf signifikansi $5 \%$ dengan $\mathrm{dk}=(38+36-2)=72$ didapatkan $\mathrm{t}_{\text {tabel }}$ 1,993. Dengan kriteria $t_{\text {hitung }}=2,979>t_{\text {tabel }}=1,993$ oleh karena itu, $H_{o}$ ditolak dan $H_{a}$ diterima. Hal ini berarti terdapat perbedaan yang signifikan kompetensi pengetahuan IPA antara kelompok siswa yang dibelajarkan menggunakan model pembelajaran group investigation berbasis media lingkungan dengan kelompok siswa yang dibelajarkan menggunakan pembelajaran konvensional pada siswa kelas V SDN Gugus I Gusti Ngurah Jelantik Kecamatan Denpasar Utara tahun pelajaran 2019/2020.

Tabel 03. Uji Hipotesis

\begin{tabular}{|c|c|c|c|c|c|c|c|c|}
\hline No & Sampel & $\mathbf{N}$ & Dk & $\overline{\mathbf{X}}$ & $\mathbf{S}^{2}$ & thitung & $\mathbf{t}_{\text {tabel }}$ & Simpulan \\
\hline 1 & $\begin{array}{c}\text { Kelas } \\
\text { Eksperimen }\end{array}$ & 38 & \multirow{2}{*}{72} & 0,4 & 0,020441 & \multirow{2}{*}{2,979} & \multirow[b]{2}{*}{1,993} & \multirow{2}{*}{$\mathrm{H}_{\mathrm{o}}$ ditolak } \\
\hline 2 & $\begin{array}{c}\text { Kelas } \\
\text { Kontrol }\end{array}$ & 36 & & 0,23 & 0,013818 & & & \\
\hline
\end{tabular}

\section{PEMBAHASAN}

Berdasarkan dari hasil uji-t diperoleh bahwa dengan kriteria thitung $>$ ttabel yaitu thitung $=2,979>$ ttabel $=1,993$. Dengan demikian, dapat dinyatakan bahawa H0 ditolak serta diperoleh perbedaan yang signifikan kompetensi pengetahuan IPA siswa kelas eksperimen yang dibelajarkan dengan model Group Investigation. Dari analisis data kompetensi pengetahuan IPA yang telah dilaksanakan didapatkan nilai rata-rata pada kelompok eksperimen $\bar{X}=0,4$. Pada analisis data kompetensi pengetahuan IPA kelompok kontrol diperoleh nilai rata-rata $\bar{X}=0,23$. Berdasarkan hasil perhitungan data gain score ternormalisasi kompetensi pengetahuan IPA, menunjukkan bahwa rata-rata gain score ternormalisasi kelompok eksperimen lebih dari rata-rata gain score ternormalisasi kelompok kontrol. Rata-rata gain skor kompetensi pengetahuan IPA siswa pada kelompok eksperimen yang dibelajarkan menggunakan model pembelajaran group investigation berbasis media lingkungan lebih tinggi dari kelompok kontrol yang dibelajarkan tanpa melalui model pembelajaran group investigation berbasis media lingkungan dengan perolehan $(\overline{X=0,4}>\bar{X}=0,23)$. Ini menunjukan bahwa kelompok yang dibelajarkan melalui 
model pembelajaran group investigation berbasis media lingkungan memiliki pengaruh yang lebih baik daripada kelompok yang dibelajarkan tanpa melalui model pembelajaran group investigation berbasis media lingkungan terhadap kompetensi pengetahuan IPA siswa. Karena terdapat perbedaan yang signifikan dan rata-rata gain skor kelompok eksperimen lebih tinggi daripada kelompok kontrol, maka model pembeklajaran group investigation berbasis media lingkungan berpengaruh terhadap kompetensi pengetahuan IPA siswa kelas V SDN Gugus I Gusti Ngurah Jelantik tahun ajaran 2019/2020.

Model pembelajaran Group Investigation berbasis media lingkungan dapat dipergunakan sebagai inovasi dalam pembelajaran yang menuntut keaktifan siswa karena dalam proses pembelajaran, siswa memiliki kebebasan dalam memilih materi yang mereka pelajari sesuai dengan topik yang sedang dibahas yang disediakan oleh guru yang nantinya langsung diselidiki dan dipresentasikan serta dalam penerapan model selalu menyertakan media lingkungan sekolah sebagai salah satu sumber informasi belajar untuk siswa dalam mengeksplor pengetahuannya melalui benda atau alat yang berada di lingkungan sekolahnya, maka suasana yang diciptakan lebih menarik, efektif dan tidak membosankan bagi siswa serta meningkatkan komunikasi siswa dengan seluruh anggota kelompoknya, anggota kelompok lain dan dengan guru dalam proses konfirmasi diakhir pembelajarannya. Pada penelitian ini memberikan implikasi terhadap pembelajaran yang terdapat pada sekolah dasar. Implikasi teoretis yaitu pemilihan model pembelajaran yang sesuai pada saat kegiatan pembelajaran dapat memberikan dampak positif siswa terhadap kompetensi pengetahuan IPA. Sedangkan implikasi secara praktis yaitu penelitian ini juga mampu menunjang ataupun memperkuat penelitian lain di kedepannya serta sebagai suatu acuan dalam proses pembelajaran agar menjadi lebih baik dengan memvariasikan metode lain dan menyesuaikan keadaan di lapangan. Hasil penelitian ini dapat digeneralisasikan di populasi penelitian. Hal ini berarti bahwa model pembelajaran Group Investigation berbasis media lingkungan dapat diterapkan diseluruh sekolah dasar negeri yang berada di Gugus I Gusti Ngurah Jelantik Denpasar tahun pelajaran 2019/2020.

Hasil temuan penelitian pada penelitian ini memiliki persamaan dengan penelitian yang relevan sebelumnya dan memperkuat hasil penelitian yang diperoleh. Hal ini didukung hasil penelitian yang diajukan oleh Widiartini (2019) yang mengungkapkan bahwa penerapan model pembelajaran group investigation berkontribusi meningkatkan interaksi siswa karena pada model ini siswa diberikan kesempatan untuk berdiskusi dan berinteraksi dengan temannya dalam menemukan dan memahami suatu konsep. Setiap anggota kelompok juga bertanggungjawab atas segala sesuatu yang dikerjakan dalam kelompoknya, sehingga setiap siswa tidak ada yang diam. Siswa bertanggung jawab akan keberhasilan kelompoknya. Siswa saling bekerjasama dalam menyusun jawaban.

\section{SIMPULAN}

Berdasarkan penelitian dan pembahasan yang telah dilaksanakan, maka dapat disimpulkan bahwa penerapan model pembelajaran Group Investigation berbasis media lingkungan berpengaruh secara signifikan terhadap kompetensi pengetahuan IPA siswa kelas V SDN Gugus I Gutsi Ngurah Jelantik Denpasar tahun ajaran 2019/2020. Hal ini dibuktikan dengan rata-rata gain skor kompetensi pengetahuan IPA pada kelompok eksperimen lebih dari rata-rata gain skor kompetensi pengetahuan IPA kelompok kontrol serta hasil uji hipotesis menggunakan uji t memperoleh thitung lebih dari ttabel. Karena thitung lebih dari ttabel maka Ho ditolak dan Ha diterima. Sehingga model Group Investigation berbasis media lingkungan memiliki pengaruh terhadap kompetensi pengetahuan IPA siswa kelas V SD Gugus I Gusti Ngurah Jelantik Denpasar tahun ajaran 2019/2020. 


\section{DAFTAR PUSTAKA}

Agung, A. A. G. (2014). Buku Ajar Metodologi Penelitian Pendidikan. Aditya Media Publishing.

Aisyah. (2018). Pengaruh Model Group Investigation Terhadap Kemampuan Berpikir Tingkat Tinggi Ipa. Jurnal Pendidikan Guru Sekolah Dasar.

Anjelina Putri, A. A., Swatra, I. W., \& Tegeh, I. M. (2018). pengaruh model pembelajaran PBL berbantuan media gambar terhadap hasil belajar IPA siswa kelas III SD. Mimbar Ilmu. https://doi.org/10.23887/mi.v23i1.16407

Arikunto, S. (2015). Dasar - Dasar Evaluasi Pendidikan. Bumi Aksara.

Aris, S. (2014). 68 Model Pembelajaran Inovatif dalam Kurikulum 2013. Ar-Ruzz Media.

Buchari, A. (2018). peran guru dalam pengelolaan pembelajaran. Jurnal Ilmiah Iqra'. https://doi.org/10.30984/jii.v12i2.897

Diah Purwati, N. L. P., Wibawa, I. M. C., \& Margunayasa, I. G. (2019). Pengaruh Numbered Head Together Berbantuan Gambar Terhadap Penguasaan Kompetensi Pengetahuan IPA. Jurnal Pedagogi Dan Pembelajaran. https://doi.org/10.23887/jp2.v2i3.19275

Diantari, P., Wiarta, I. W., Agung, I. G., \& Negara, O. (2014). pengaruh model pembelajaran problem based learning berbasis hypnoteaching terhadap hasil belajar matematika siswa kelas V SD Jurusan Pendidikan Guru Sekolah Dasar, FIP Universitas Pendidikan Ganesha. Jurnal Mimbar PGSD Universitas Pendidikan Ganesha.

Dra. Ni Wayan Suniasih, S., \& Drs. I Wayan Sujana, S. (2017). Pengaruh Model Pembelajaran Talking Chips Berbasis Tri Hita Karana Terhadap Kompetensi Pengetahuan Ips. MIMBAR PGSD Undiksha, 5(2). https://doi.org/10.23887/jjpgsd.v5i2.10659

Febbriana, I. R. A., Ardana, I. K., \& Agustika, G. N. S. (2019). Pengaruh Model Pembelajaran Word Square Berbasis Outdoor Study Terhadap Kompetensi Pengetahuan IPA Siswa. mimbar PGSD Undiksha.

Junaidi, J., Ariani, T., \& Arini, W. (2019). Pengaruh Model Pembelajaran Word Square terhadap Hasil Belajar Fisika. Science and Physics Education Journal (SPEJ). https://doi.org/10.31539/spej.v2i2.726

Karwati, N. P. R. (2018). Pengaruh Model Pembelajaran Probing Prompting Berbantuan Multimedia Terhadap Hasil Belajar Ipa. Jurnal Penelitian Dan Pengembangan Pendidikan. https://doi.org/10.23887/jppp.v2i2.15386

Lasfeto, A. R. (2017). Meningkatkan Hasil Belajar Ipa Melalui Model Group Investigation Berbantuan Video Pada Siswa Sekolah Dasar. Jurnal Penelitian Dan Pengembangan Pendidikan, 1(3), 1-7. https://doi.org/10.23887/jppp.v1i3.12631

Machali, I. (1970). Kebijakan Perubahan Kurikulum 2013 dalam Menyongsong Indonesia Emas Tahun 2045. Jurnal Pendidikan Islam. https://doi.org/10.14421/jpi.2014.31.7194

MASHLICHATUN NIMAH, S. (2018). Pengaruh Model Pembelajaran Kooperatif Tipe Group Investigation Terhadap Hasil Belajar Ipa Siswa Kelas Iv Sekolah Dasar. Jurnal Penelitian Pendidikan Guru Sekolah Dasar, 6(11), 264-271.

Program, D. I., Pendidikan, S., \& Ftk, K. (2016). Lantanida Journal, Vol. 4 No. 2, 2016. $4(2)$. 
Purnawan, I. (2018). Pengaruh Model Problem Based Learning Berbantuan Media Animasi Terhadap Kompetensi Pengetahuan Ipa Siswa Kelas V. Jurnal Imiah Pendidikan Dan Pembelajaran, 2(2), 211-218. https://doi.org/10.23887/jipp.v2i2.15404

Putra, P. G. N., Margunayasa, I. G., \& Wibawa, I. M. C. (2019). Pengaruh Model Pembelajaran Kooperatif Tipe Group Investigation (GI) Berbasis Lesson Study Terhadap Penguasaan Konsep IPA. Jurnal Pedagogi Dan Pembelajaran, 1(2), 84. https://doi.org/10.23887/jp2.v1i2.19329

Putri, ni made suandayani ari, Suniasih, ni wayan, \& Wiarta, W. (2013). pengaruh model pembelajaran kooperatif tipe make a match berbasis media lingkungan terhadap hasil belajar ipa siswa kelas IV sekolah dasar. English Education Department, 5-12.

Putri, N. M. C. N. M., Ardana, I. K., \& Agustika, G. N. S. (2019). Pengaruh Model Discovery Learning Berbantuan Lingkungan Terhadap Kompetensi Pengetahuan IPA Siswa Kelas V. Mimbar PGSD.

Rivaldi, K. H. O., Putra, D. K. N. S., \& Putra, I. K. A. (2018). Pengaruh Model Pembelajaran Problem Based Learning Berbantuan Audio Visual Terhadap Penguasaan Kompetensi Pengetahuan IPA. Jurnal Ilmiah Sekolah Dasar. https://doi.org/10.23887/jisd.v2i2.15494

Santika Dewi, N. P., Ardana, I. K., \& Putra, M. (2018). pengaruh model pembelajaran learning cycle $5 \mathrm{E}$ berbantuan media lingkungan terhadap kompetensi pengetahuan IPA kelas IV. Jurnal Imiah Pendidikan Dan Pembelajaran. https://doi.org/10.23887/jipp.v2i3.16237

Sujana, I. W. C. (2019). fungsi dan tujuan pendidikan indonesia. Adi Widya: Jurnal Pendidikan Dasar. https://doi.org/10.25078/aw.v4i1.927

Sujarwo, S. (2015). pendidikan di indonesia memprihatinkan. Jurnal Ilmiah WUNY. https://doi.org/10.21831/jwuny.v15i1.3528

Sumertha, I. G. (2019). Penerapan Model Pembelajaran Kooperatif Tipe Group Investigation (GI) untuk Meningkatkan Hasil Belajar IPA Siswa. Jurnal Pedagogi Dan Pembelajaran. https://doi.org/10.23887/jp2.v2i2.17908

Triyana, A., Rara, Y., Agung, I. G., \& Negara, O. (2020). Pengaruh Model Pembelajaran ( SAVI ) Berbantuan Multimedia Terhadap Kompetensi Pengetahuan IPA. 8, 40-49.

Wibowo, M. E. (2019). Peningkatan keaktifan siswa melalui penerapan model pembelajaran kooperatif tipe group investigation. Pendidikan Guru Sekolah Dasar, 2.

Widiartini, P. D. O., Made Putra, M. P., \& Manuaba, I. B. S. (2019). Pengaruh Model Pembelajaran Group Investigation Berbasis Tri Hita Karana Terhadap Kompetensi Pengetahuan IPA. Jurnal Ilmiah Sekolah Dasar. https://doi.org/10.23887/jisd.v3i3.19476

Yanti, N. L. M. S. M. (2017). Pengaruh Model Pembelajaran Creative Problem Solving Berbasis Educative Games Terhadap Kemampuan Berpikir Kritis dan Hasil Belajar Ipa Kelas IV Di Gugus IV Kecamatan Kuta, Kabupaten Badung. Jurnal Ilmiah Pendidikan Dan Pembelajaran. https://doi.org/10.23887/JIPP.V1I2.11967

Zubaidah, S. (2016). Keterampilan Abad Ke-21: Keterampilan Yang Diajarkan Melalui Pembelajaran. Seminar Nasional Pendidikan. https://doi.org/10.1021/acs.langmuir.6b02842 